\title{
Odpověd' na diskusi ke článku J. Hradec, J. Bultas, A. Kmínek, et al. Jak se léčí statiny v České republice? Výsledky průzkumu STEP [Cor et Vasa 53 (2011) 527-534]
}

Pan MUDr. Rudolf Gaško ve svém diskusním příspěvku upozorňuje na to, že stanovení LDL cholesterolu výpočtem pomocí Friedewaldovy rovnice je nepřesné a vypočtené hodnoty se $v$ některých laboratořích významně odchylují od hodnot získaných metodami prímého měření LDL cholesterolu. Dokládá to výsledky multicentrické studie, ve které se svými spolupracovníky srovnával výsledky prrímého měření LDL cholesterolu s hodnotami získanými výpočtem pomocí Friedewaldovy rovnice $v$ několika náhodně vybraných laboratořích v ČR a SR. V této multicentrické studii zjistili rozdíly mediánů hodnot LDL cholesterolu získaných oběma metodami od $-26 \%$ do +59 \%. To by znamenalo, že hodnoty LDL cholesterolu stanovené různými metodami v různých laboratořích jsou naprosto nesrovnatelné, a proto $v$ klinické praxi naprosto nepoužitelné.

Souhlasíme s tím, že stanovení LDL cholesterolu v jedné centrální laboratoři by nepochybně přineslo přesnější výsledky, ale za cenu mnohonásobně vyšších finančních nákladů. Finančních nákladů natolik vysokých, že se odesílání krevních vzorků k analýzám v centrální laboratoři nepoužívá ani u všech randomizovaných dvojitě zaslepených intervenčních klinických studií, natož v epidemiologických průzkumech. Navíc náš průzkum, jak výslovně ríká jeho název (Statin Therapy REsults in the Real World Practice in the (zech Republic), měl přinést informace $z$ reálného světa a $k$ reálnému světu klinické praxe rozhodně nepatří odesílání krevních vzorků k biochemickému vyšetření do jedné centrální laboratoře.

Domníváme se, že výpočet LDL cholesterolu podle Friedewaldovy rovnice je zcela bezproblémový, pokud se respektuje skutečnost, že plazmatická koncentrace triglyceridů musí být $<4 \mathrm{mmol} / \mathrm{l}$. Na druhé straně jsou jisté problémy se standardizací metody prímého stanovení LDL cholesterolu, protože pro různé komerčně vyráběné kity existují různé kalibrátory. Existuje však také systém externího hodnocení kvality biochemických laboratoří (EHK), který zajištuje, že výsledky stanovení biochemických parametrů (nejenom lipidových) v jednotlivých laboratořích jsou dostatečně spolehlivé a mezi jednotlivými laboratořemi srovnatelné. To, co MUDr. R. Gaško ve svém diskusním příspěvku uvádí, by bylo známkou naprostého selhání systému EHK našich klinických laboratoří.

Prof. MUDr. Jaromír Hradec, CSC., III. interní klinika, 1. lékařská fakulta Univerzity Karlovy a Všeobecná fakultní nemocnice, Praha, e-mail: jhradec@vfn.cz 